\title{
TINGKAT PENGETAHUAN REMAJA PUTRI TERHADAP KEPUTIHAN DI DESA GASARIBU KECAMATAN LAGUBOTI KABUPATEN TOBA SAMOSIR
}

\author{
Melva Manurung, Putri Sitorus \\ Program Studi D-III Keperawatan, STIKes Arjuna \\ E-mail : melva_manroe84@yahoo.com
}

\begin{abstract}
Reproductive health is one indicator the quality and accessibility of health service facilities. One of the clinical complaints of adolescent reproduction is vaginal discharge. Leucorrhoea is defined as discharge from the vagina. These fluids vary in consistency (solid, liquid, viscous), in color (clear, white, yellow, green) and odor (normal, smelly). This study aims to identify the level of knowledge of young women about vaginal discharge at Gasaribu Village, Laguboti District in 2020. The sample was determined using a simple random sampling technique, as many as 65 people. Data collection was carried out in July 2020 using a questionnaire containing statements about demographic data, and vaginal discharge. Based on the results of research conducted in Sitoluama Village, Laguboti District, regarding the knowledge of adolescents about the causes of vaginal discharge, it is known that the knowledge of young women about vaginal discharge from 65 respondents 17 people with good knowledge (26.2\%), sufficient knowledge of 35 people $(53.8 \%)$, less knowledgeable 13 people (20\%).
\end{abstract}

Keywords : Level Of Knowledge, Young Women, Vaginal Discharge

\begin{abstract}
Abstrak
Kesehatan repoduksi merupakan salah satu indikator yang peka terhadap kualitas dan aksesibilitas fasilitas pelayanan kesehatan. Salah satu keluhan klinis dari reproduksi remaja adalah keputihan. Keputihan didefinisikan sebagai keluarnya cairan dari vagina. Cairan tersebut bervariasi dalam konsistensi (padat, cair, kental), dalam warna (jernih, putih, kuning, hijau) dan bau (normal, berbau). Penelitian ini bertujuan untuk mengidentifikasi tingkat pengetahuan remaja putri tentang keputihan di Desa Gasaribu Kecamatan Laguboti tahun 2020. Penentuan sampel menggunakan teknik simple random sampling yaitu sebanyak 65 orang. Pengumpulan data dilakukan pada bulan Juli 2020 menggunakan kuesioner yang berisi pernyataan tentang data demografi, dan keputihan. Berdasarkan hasil penelitian yang telah dilakukan di Desa Sitoluama Kecamatan Laguboti tentang pengetahuan remaja tentang penyebab keputihan, diketahui bahwa pengetahuan remaja putri tentang keputihan dari 65 responden 17 orang berpengetahuan baik $(26,2 \%)$, pengetahuan cukup 35 orang $(53,8 \%)$, berpengetahuan kurang 13 orang $(20 \%)$.
\end{abstract}

Kata Kunci : Tingkat Pengetahuan, Remaja Putri, Keputihan

\section{PENDAHULUAN}

Pembangunan kesehatan adalah tercapainya kemampuan hidup sehat bagi setiap penduduk atau individu agar dapat mewujudkan derajat kesehatan masyarakat yang optimal. Salah satu target yang telah ditentukan dalam Millennium Development Goals (MDGs, 2015) pada rencana kelima yaitu mewujudkan akses kesehatan reproduksi bagi semua perempuan (Kemenkes, 2016).

Kesehatan repoduksi merupakan salah satu indikator yang peka terhadap kualitas dan aksesibilitas fasilitas pelayanan kesehatan. Di Indonesia, kesehatan dan jasajasa lainnya secara umum semakin lama 
mulai menanggapi kebutuhan-kebutuhan dan permintaan dari kebanyakan remaja. Sejumlah proyek dan program yang didukung oleh pemerintah dengan atau tanpa bantuan donatur telah ada selama beberapa waktu, namun kebanyakan dari mereka hanya berfokus pada sejumlah isu-isu yang terbatas saja yang berhubungan dengan remaja dan tidak pada kebutuhan mereka secara keseluruhan (Kemenkes, 2017).

Fokus projek untuk tahun 2004-2005 adalah untuk mendukung pengembangan lebih lanjut dari rencana pembangunan remaja nasional dan daerah dan pelaksanaannya, termasuk kebutuhan koordinasi antara para mitra, akses dan mutu dari jasa kesehatan yang ramah remaja dalam konteks pendekatan yang lebih "ramah publik" dan akses bagi remaja ke informasi yang dapat diandalkan dan relevan yang mana remaja dapat mendasarkan keputusannya (Rahman, 2013).

Kesehatan reproduksi remaja tidak lepas dari kesehatan di bidang kebidanan dan kandungan. Hingga saat ini masih banyak dijumpai penyakit infeksi yang mengganggu alat reproduksi wanita. Di Indonesia saat ini belum ada data nasional yang bisa digunakan sebagai penunjuk status kesehatan reproduksi remaja. Namun, beberapa penelitian akhirakhir ini menunjukkan bahwa remaja Indonesia beresiko untuk terkena infeksi PMS/ HIV/ AIDS (Masroah et al, 2015)

Keputihan merupakan gejala yang sangat sering dialami oleh sebagian besar wanita. Gangguan ini merupakan masalah kedua sesudah gangguan haid. Keputihan seringkali tidak ditangani dengan serius oleh para remaja. Padahal, keputihan bisa jadi indikasi adanya penyakit. Hampir semua perempuan pernah mengalami keputihan. Pada umumnya, orang menganggap keputihan pada wanita sebagai hal yang normal. Pendapat ini tidak sepenuhnya benar, karena ada berbagai sebab yang dapat mengakibatkan keputihan. Keputihan yang normal memang merupakan hal yang wajar. Namun, keputihan yang tidak normal dapat menjadi petunjuk adanya penyakit yang harus diobati.
Hasil penelitian menyebutkan 3 dari 4 wanita di dunia ternyata pernah mengalami keputihan setidaknya sekali dalam hidupnya. Setiap wanita bisa terkena gangguan ini tanpa melihat golongan usia, latar belakang, dan jenis pekerjaan. Di Indonesia masalah keputihan semakin meningkat. Dari hasil penelitian menyebutkan bahwa tahun 2002, $50 \%$ wanita Indonesia pernah mengalami keputihan setidaknya sekali dalam hidupnya (Muninjaya, 2015).

Menurut Manuaba (2011) infeksi pada vulva yang lazim disebut vulvitis sebagian besar dengan gejala keputihan atau leukorea dan tanda infeksi lokal. Keputihan didefinisikan sebagai keluarnya cairan dari vagina. Cairan tersebut bervariasi dalam konsistensi (padat, cair, kental), dalam warna (jernih, putih, kuning, hijau) dan bau (normal, berbau). Sebagian wanita menganggap cairan yang keluar dari vagina masalah biasa ada juga yang menganggap masalah keputihan mengganggu aktivitas sehari-hari. Masalah yang perlu diwaspadai adalah apakah keputihan tersebut normal atau ada sesuatu kelainan/ penyakit.

Jika keputihan menyebabkan gatalgatal dan nyeri di dalam vagina, atau di sekeliling saluran pembuka vulva, kondisi ini secara umum disebabkan oleh penyakit, dan tentunya memerlukan pemeriksaan. Tiga jenis utama gangguan dapat menimbulkan masalah, yaitu candidiasis penyebab paling umum gatal-gatal pada vagina. Infeksi sering mengenai vulva dan menimbulkan gatalgatal. Jamur menyerang sel pada saluran vagina dan sel kulit vulva. Pada beberapa wanita, jamur masuk ke lapiran sel yang lebih dalam dan beristirahat di sana sampai diaktifkan kembali karena satu alasan. Sel-sel yang terinfeksi tidak teralu parah gugur ke dalam vagina, sehingga menyebabkan keputihan. Sekitar $15 \%$ wanita terinfeksi, tetapi gejala keputihan dan gatal-gatal terjadi hanya dalam $3 \%$ sampai $5 \%$ wanita (Muninjaya, 2005).

Keluarnya cairan dari vagina adalah normal pada usia reproduksi, cairan tersebut jumlahnya tidak banyak, jernih, tidak bau dan tidak gatal. Secara alami cairan yang keluar 
merupakan produksi dari kelenjar di mulut rahim, bercampur dengan sel-sel vagina, bakteri dan sekresi kelenjar-kelenjar di jalan lahir. Secara fisiologis keluarnya cairan dapat dijumpai pada saat ovulasi, saat menjelang dan setelah haid, rangsangan seksual, dan dalam kehamilan. Sifat dan banyaknya keputihan dapat memberi petunjuk ke arah penyebab. Demikian pula halnya dengan indikasi lain seperti lama keluhan, terus menerus atau pada waktu tertentu saja, warna, bau disertai rasa gatal atau tidak (Iskandar, 2012).

Secara alamiah bagian tubuh yang berongga dan berhubungan dengan dunia luar akan mengeluarkan semacam getah atau lendir. Demikian pula halnya dengan saluran kelamin wanita (vagina). Dalam keadaan normal, getah atau lendir vagina adalah cairan bening tidak berbau, jumlahnya tidak terlalu banyak dan tanpa rasa gatal atau nyeri (Rahmi, Egi Yunia, 2016). Keputihan apabila tidak segera diobati dapat berakibat lebih parah dan bukan tidak mungkin menjadi penyebab kemandulan. Penyebab keputihan berlebihan terkait dengan cara kita merawat organ reproduksi. Misalnya, mencucinya dengan air kotor, memakai pembilas secara berlebihan, menggunakan celana yang tidak menyerap keringat, jarang mengganti celana dalam, tak sering mengganti pembalut (Wahyurini dan Masum, 2005).

Hampir semua wanita pernah mengalami keputihan, bahkan ada yang sampai merasa sangat terganggu. Namun, rasa malu untuk diperiksa pada bagian bawah tubuh yang satu ini, sering kali mengalahkan keinginan untuk sembuh. Belum lagi masyarakat kita yang tidak terbiasa memeriksa alat kelamin sendiri, sehingga kalau ada gangguan tertentu tidak segera bisa diketahui (Wandha \& Misrawati, 2012).

Rasa malu untuk periksa ke dokter juga menyebabkan banyak wanita mencoba untuk mengobati keputihannya sendiri, baik dengan obat yang dibeli di toko obat, maupun dengan ramuan tradisional. Apabila pengobatan yang dilakukan tidak sesuai dengan jenis penyebab keputihan tersebut, tentu saja pengobatan akan sia-sia. Bahkan, bisa jadi justru menyebabkan kerugian yang lain. Mestinya, rasa malu tersebut dibuang jauh-jauh. Apalagi, jika mengingat betapa seriusnya akibat yang dapat ditimbulkan oleh keputihan yang berkepanjangan tanpa penanganan yang tuntas (Wahyurini, 2005).

Para remaja harus waspada terhadap gejala keputihan. Penelitian menunjukkan, keputihan yang lama walau dengan gejala biasa-biasa saja, lama kelamaan dapat merusak selaput dara. Sebagian besar cairan itu mengandung kuman-kuman penyakit, dan kuman penyakit dapat merusak selaput dara sampai hampir habis, sehingga pada saat hubungan badan yang pertama tidak mengeluarkan darah.

Berdasarkan data pra survey terhadap 10 remaja putri yang berusia 10-19 tahun di Desa Gasaribu Kecamatan Laguboti pada bulan Desember tahun 2019, didapat bahwa 7 dari 10 remaja putri tersebut yang mengalami keputihan mengatakan tidak mengetahui tentang pengertian, penyebab dan perawatan yang harus dilakukan jika terjadi keputihan. Oleh karena itu, penulis tertarik untuk melakukan penelitian tentang "Tingkat pengetahuan remaja putri terhadap keputihan di Desa Gasaribu Kecamatan Laguboti”.

\section{METODOLOGI PENELITIAN}

Jenis penelitian ini menggunakan metode deskriptif yaitu suatu metode penelitian yang dilakukan dengan tujuan utama untuk membuat gambaran atau deskripsi tentang suatu keadaan secara objektif. Populasi dalam penelitian ini adalah remaja putri usia 13-19 tahun di Desa Gasaribu Kecamatan Laguboti tahun 2020 yang berjumlah 176 orang. Sampel adalah sebagian yang diambil dari keseluruhan objek yang diteliti dan dianggap mewakili seluruh populasi yang berjumlah 65 orang. Penelitian dilaksanakan pada bulan Juli 2020.

HASIL PENELITIAN

Pengetahuan Remaja Putri Terhadap Pengertian Keputihan Di Desa Gasaribu Kecamatan Laguboti Tahun 2020

Tabel 1. Distribusi Frekwensi Responden Pengetahuan Remaja Putri Tentang 
Keputihan di Desa Gasaribu Kecamatan Laguboti

\begin{tabular}{cccc}
\hline No & Pengetahuan & Frekwensi & Persentase \\
\cline { 3 - 4 } & & $\mathbf{n}$ & $\mathbf{( \% )}$ \\
\hline 1 & Baik & 17 & 26,2 \\
2 & Cukup & 35 & 53,8 \\
3 & Kurang & 13 & 20,0 \\
\hline \multicolumn{1}{c}{ Total } & $\mathbf{6 5}$ & $\mathbf{1 0 0}$ \\
\hline
\end{tabular}

Dari tabel 1 diketahui bahwa pengetahuan remaja putri tentang keputihan dari 65 responden 17 orang berpengetahuan baik $(26,2 \%)$, pengetahuan cukup 35 orang $(53,8 \%)$, berpengetahuan kurang 13 orang $(20 \%)$.

\section{PEMBAHASAN}

Hasil penelitian pengetahuan remaja putri tentang keputihan di Desa Gasaribu adalah mayoritas 17 orang berpengetahuan baik $(26,2 \%)$, pengetahuan cukup $(53,8 \%)$. Hasil penelitian ini sesuai dengan penelitian yang dilakukan oleh Celly di Desa Krembangan kecamatan Gudo tahun 2010 remaja putri tentang keputihan", yang melaporkan bahwa pengetahuan wanita tentang keputihan dalam kategori cukup yaitu 21 orang, berpengetahuan baik 14 orang dan berpengetahuan kurang 10 orang.

Masalah keputihan adalah masalah yang sejak lama menjadi persoalan bagi kaum wanita. Tidak banyak wanita yang tahu apa itu keputiahan dan terkadang menganggap enteng persoalan keputihan ini. Padahal keputihan tidak bisa dianggap enteng, karena akibat dari keputihan ini bisa sangat fatal bila lambat ditangani. Tidak hanya bisa mengakibatkan kemandulan dan hamil di luar kandungan, keputihan juga bisa merupakan gejala awal dari kanker leher rahim, yang bisa berujung pada kematian (Iskandar, 2012). Menurut penyebabnya keputihan ada dua macam yaitu penyebab non potologis (bukan penyakit) dan penyebab patologis (karena penyakit). Penyebab non patologis (bukan penyakit) antara lain saat menjelang menstruasi, atau setelah menstruasi, rangsangan seksual, saat wanita hamil, stress, baik fisik maupun psikologi (Wiknjosastro, H. 2012).
Berdasarkan umur yang mendapat pengetahuan tentang keputihan di Desa Gasaribu Kecamatan Laguboti, hasil penelitian didapatkan sebagian besar umur 13-16 tahun sejumlah 37 orang dan umur > 17 tahun 28 orang. Mayoritas berpengetahuan cukup, tetapi masih ada yang berpengetahuan kurang karena semakin bertambahnya usia seseorang akan semakin sulit untuk menerima informasi yang ada walaupun mungkin responden mendapatkan informasi tentang keputihan, responden tidak dapat mengingat dengan baik informasi yang telah didapat. Hal ini sesuai dengan pendapat Notoadmojo (2010) bahwa semakin bertambahnya usia seseorang maka akan menyebabkan semakin menurunnya daya ingat sehingga menyebabkan semakin sulit untuk menerima informasi.

Pengetahuan responden berdasarkan Pendidikan dari hasil penelitian di Desa Gasaribu kecamatan Laguboti terdapat 27 responden yang masih berpendidikan SMP, pada umumnya makin tinggi pendidikan seseorang makin mudah menerima informasi, sebaliknya pendidikan kurang akan menghambat perkembangan sikap seseorang terhadap nilai baru yang diperkenalkan, hal ini dapat dilihat bahwa responden masih ada yang berpengetahuan kurang, bahkan yang pendidikan SMA masih ada yang berpengetahuan kurang, penelitian ini dapat dibandingkan dengan penelitian yang dilakukan oleh Yenny chandra (2009) dengan judul "Gambaran pengetahuan wanita tentang keputihan di kelurahan petisah tengah" yang melaporkan bahwa dari 109 responden pengetahuan usia 21-50 tahun berada dalam kategori cukup yaitu sebesar 73,4 \%, sebagian besar responden berpendidikan SMA (62 \%), namun masih ada yang berpengetahuan kurang, hal ini disebabkan karena kurang mendapat informasi tentang keputihan Informasi sangat penting dalam peningkatan pengetahuan, oleh karena itu diharapkan fasilitas yang menjadi media penyampaian informasi supaya semakin meningkatkan informasi yang berhubungan dengan kesehatan khususnya keputihan. 
Hasil penelitian yang dilakukan di Desa Gasaribu kecamatan Laguboti bahwa lebih banyak responden mendapat informasi dari media elektronika (Televisi, radio), namun masih ada yang berpengetahuan kurang, sedangkan informasi yang diperoleh dari petugas kesehatan sebanyak 27 orang yang semuanya berpengetahuan baik dan cukup.

Informasi dari petugas kesehatan ternyata lebih baik karena langsung bertatap muka dan responden dapat bertanya langsung ke petugas kesehatan. Disamping itu petugas kesehatan dalam memberikan promosi kesehatan dengan leaflet, brosur yang memudahkan responden mengerti informasi yang disampaikan dan dapat dibaca ulang dirumah. Disamping itu responden yang bekerja sebagai petani yang paling dekat dengan media elektronika, diharapkan media elektronika dapat menyampaiakan informasi kesehatan yang lebih baik khususnya tentang Keputihan (Wawan \& Dewi, 2011).

Menurut Notoatmodjo (2013) pengetahuan merupakan hasil "tahu" dan terjadi setelah orang melakukan penginderaan terhadap suatu objek tertentu. Pengetahuan atau kognitif merupakan domain yang sangat penting bagi terbentuknya perilaku seseorang. Pengetahuan akan merangsang terjadinya perubahan sikap dan bahkan tindakan seseorang individu.

Tingkat pengetahuan remaja putri yang ada didesa Gasaribu juga dipengaruhi oleh faktor lingkungan ada, remaja putri yang ada dilingkungan tersebut terkadang sulit untuk diajak mengikuti acara penyuluhan tentang kesehatan dari petugas kesehatan dengan alasan sibuk dengan ke sawah dan sekolah dan penyuluhan itu tidak terlalu penting, sehingga saat dilakukan penelitian dan diukur tingkat pengetahuannya diperoleh hasil dengan pengetahuan yang cukup (Kusumaningsih, 2007)

\section{KESIMPULAN}

Berdasarkan hasil penelitian tentang pengetahuan remaja putri tentang keputihan disimpulkan yaitu remaja putri berpengetahuan baik 17 orang $(26,2 \%)$, pengetahuan cukup 35 orang $(53,8 \%)$, berpengetahuan kurang 13 orang (20\%).

\section{SARAN}

Diharapkan kepada peneliti selanjutnya untuk melakukan penelitian lanjutan terkait pemberian edukasi dalam mencegah terjadinya keputihan.

\section{REFERENSI}

Alimul, A. (2013). Riset keperawatan dan teknik penulisan ilmiah. Jakarta : Rineka Cipta.

Arikunto, S. (2006). Prosedur penelitian suatu pendekatan praktik. Jakarta: Rineka Cipta.

Kusumaningsih. (2007). Faktor penyebab keputihan. Dikutp dari http://www.organisasi.org. pada tanggal 1 Januari 2020.

Manuaba, I.G.B. (2011). Ilmu kebidanan penyakit kandungan dan $K B$. Jakarta: EGC.

Muninjaya, S. (2005). Kejadian keputihan. Dikutip dari http://www.mitra keluarga.com pada tanggal 12 Januari 2020.

Notoatmodjo, S. (2013). Ilmu kesehatan masyarakat prinsip-prinsip dasar. Jakarta: Rineka Cipta.

Panuju, P \& Umami, I. (2005). Psikologi remaja. Yogyakarta: PT Tiara Wacana Yogya.

Rahman. (2013). Hubungan Sosial. Dikutip dari http://www.indonesia.cri.cnhtm. pada tanggal 15 Januari 2020

Sarwono S, W. (2007). Psikologi remaja. Jakarta : PT. Raja Grafindo Persada.

Wawan. A \& Dewi, M. (2011). Pengetahuan, sikap dan perilaku manusia. Yogyakarta: Nuha Medika.

Wandha, P \& Misrawati. (2012). Efektifitas pendidikan kesehatan tentang hygine kewanitaan terhadap pengetahuan dan sikapremaja putri dalam menangani keputihan. Jurnal Ners Indonesia, 2012 : vol 2. Riau. UNRI 
Cetak ISSN : 2620-5564

Online ISSN : 2655-1292

Widyastuti, Y., et al. (2009). Kesehatan reproduksi. Yogyakarta: Fitramaya.

Wiknjosastro, H. (2012). Ilmu kebidanan.

Jakarta: Yayasan Bina Pustaka

Sarwono Prawirohardjo. 